\title{
Soluble Receptor for Advanced Glycation End Products (sRAGE) is decreased in patients with Juvenile Idiopathic Arthritis (ERA category) and inversely correlates with disease activity and S100A12 levels
}

\author{
Amita Aggarwal, Arpita Myles, Vishad Viswanath, Yogesh Preet Singh \\ From 18th Pediatric Rheumatology European Society (PReS) Congress \\ Bruges, Belgium. 14-18 September 2011
}

\section{Objectives}

Membrane bound receptor for advanced glycation end products (RAGE) is over-expressed in response to increasing concentrations of its ligand (eg S100A12) and triggers an inflammatory immune response. Its truncated form sRAGE acts as decoy receptor and competes for ligands thus down-modulating inflammation. Decreased sRAGE levels are associated with rheumatoid arthritis, Sjogren syndrome and Kawasaki disease, however limited data is available in JIA thus we studied its levels in JIA-ERA patients.

\section{Methods}

sRAGE levels were estimated in serum of patients with ERA $(\mathrm{n}=101)$, SoJIA and polyJIA $(\mathrm{n}=10$ each) and healthy controls $(n=45)$. Synovial fluid (SF) sRAGE was measured in ERA, RA, ReA and OA patients $(n=10)$. S100A12 levels were also measured. 24 ERA patients were followed up for 4 months. Disease activity was assessed by swollen joint count (SJC), tender joint count (TJC) and ESR.

\section{Results}

Serum sRAGE (pg/ml) level was significantly lower in patients compared to healthy controls [515 (64-1887) vs 1542 (627-3159); $\mathrm{p}<0.0001]$. In paired samples, SF had lower levels compared to corresponding plasma level [102 (51-799) vs 481 (134-1006); $\mathrm{p}<0.0001]$.

S100A12 (ng/ml) was higher in SF (1042; 573-1415) than sera $(638 ; 208-779)$. Serum sRAGE negatively correlated with S100A12 levels $(r=-0.474 ; \mathrm{p}<0.01$.), ESR $(r=$
-0.306; $\mathrm{p}<0.01), \mathrm{SJC}(\mathrm{r}=-0.237 ; \mathrm{p}<0.05)$ but not with TJC $(\mathrm{r}=-0.134 ; \mathrm{p}=\mathrm{ns})$. The levels of sRAGE remained stable over time in patients with stable disease.

\section{Conclusion}

sRAGE levels are reduced in patients with ERA and negatively correlate with disease activity and S100A12 levels. sRAGE may be a modulator of inflammation in these patients.

Published: 14 September 2011

doi:10.1186/1546-0096-9-S1-P179

Cite this article as: Aggarwal et al:: Soluble Receptor for Advanced Glycation End Products (sRAGE) is decreased in patients with Juvenile Idiopathic Arthritis (ERA category) and inversely correlates with disease activity and S100A12 levels. Pediatric Rheumatology 2011 9(Suppl 1):P179.

Submit your next manuscript to BioMed Central and take full advantage of:

- Convenient online submission

- Thorough peer review

- No space constraints or color figure charges

- Immediate publication on acceptance

- Inclusion in PubMed, CAS, Scopus and Google Scholar

- Research which is freely available for redistribution
() Biomed Central

() 2011 Aggarwal et al; licensee BioMed Central Ltd. This is an open access article distributed under the terms of the Creative Commons Attribution License (http://creativecommons.org/licenses/by/2.0), which permits unrestricted use, distribution, and reproduction in any medium, provided the original work is properly cited. 